
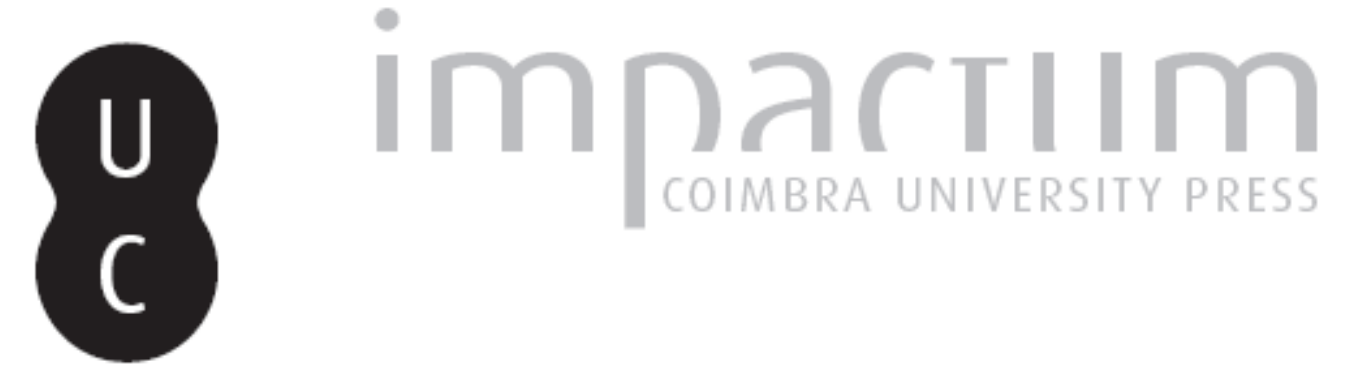

\title{
The past and future of Israel
}

\section{Autor(es): Dowty, Alan}

Publicado por: Imprensa da Universidade de Coimbra

URL persistente:

URl:http://hdl.handle.net/10316.2/36565

DOI:

DOI:http://dx.doi.org/10.14195/1647-8622_8_2

Accessed : $\quad$ 26-Apr-2023 15:21:56

A navegação consulta e descarregamento dos títulos inseridos nas Bibliotecas Digitais UC Digitalis, UC Pombalina e UC Impactum, pressupõem a aceitação plena e sem reservas dos Termos e Condições de Uso destas Bibliotecas Digitais, disponíveis em https://digitalis.uc.pt/pt-pt/termos.

Conforme exposto nos referidos Termos e Condições de Uso, o descarregamento de títulos de acesso restrito requer uma licença válida de autorização devendo o utilizador aceder ao(s) documento(s) a partir de um endereço de IP da instituição detentora da supramencionada licença.

Ao utilizador é apenas permitido o descarregamento para uso pessoal, pelo que o emprego do(s) título(s) descarregado(s) para outro fim, designadamente comercial, carece de autorização do respetivo autor ou editor da obra.

Na medida em que todas as obras da UC Digitalis se encontram protegidas pelo Código do Direito de Autor e Direitos Conexos e demais legislação aplicável, toda a cópia, parcial ou total, deste documento, nos casos em que é legalmente admitida, deverá conter ou fazer-se acompanhar por este aviso.

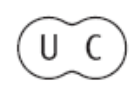




\section{cultura: imagens e representações}

ESTUDOSDOSÉCULO

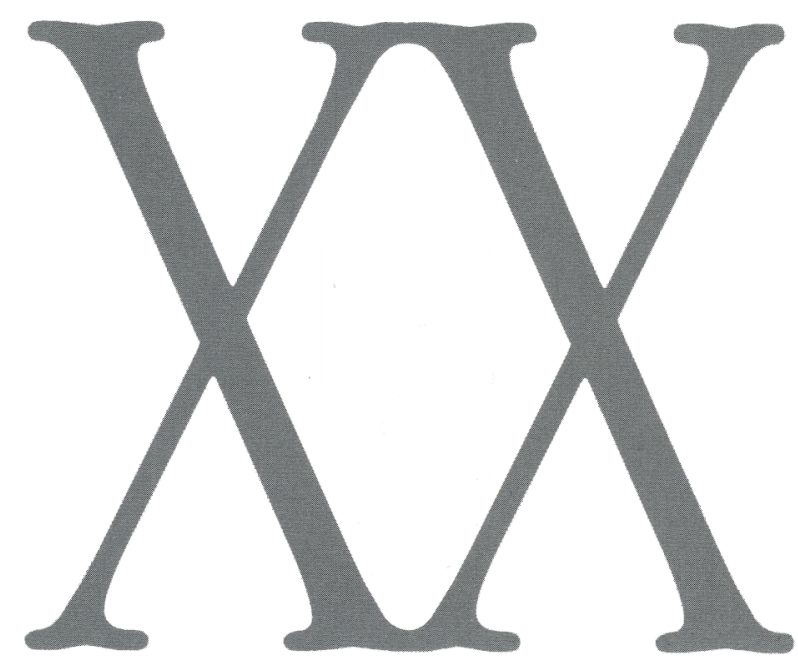

número $8 \cdot 2008$

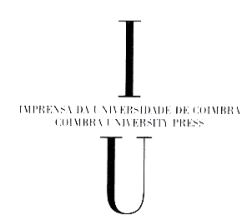




\section{The Past and Future of Israel}

\section{Alan Dowty}


Alan Dowty. Professor Emérito de Ciência Política da Universidade de Notre Dame (EUA), é um especialista de renome mundial em Relaçōes Internacionais, Médio Oriente, Relaçóes Israelo-Árabes e Conflito Israelo-Palestiniano. Doutorado pelo Departamento de História da Universidade de Chicago. 


\section{The Past and the Future of Israel ${ }^{1}$}

On May 14, 1948, the Provisional State Council of the Jewish community in the British Mandate of Palestine declared the independence of a Jewish state, to be named Israel. For Jews, this miraculous re-emergence of a Jewish state after 2000 years was one of the greatest historical moments, if not the very greatest, in their long history. Golda Meir later recollected, "My eyes filled with tears, and my hands shook. We had done it... Now we were a nation like other nations, master for the first time in 20 centuries of our own destiny."

But the events of 1948 need to be seen as part of a broader development, going back another 60 years to the beginning of the Zionist movement. I will focus here on this entire extraordinary story, going back over 120 years. We will look at four questions:

First of all, how did this happen? What strange combination of historical circumstances could explain this extraordinary development?

Secondly, how did this create a clash between two peoples over the same piece of land? Was the Arab-Israeli conflict predictable and preordained?

The third question is: What are the challenges and obstacles that face the state of Israel today. Do they pose a threat to the well-being, if not the very survival, of the country?

Finally, what are the responses to these challenges, and what does all of this mean for the future of Israel?

\section{The Emergence of Israel}

The emergence of the state of Israel was, by all accounts, one of the most remarkable developments of the twentieth century. As late as 1880 , there was no "Palestine" on anyone's map, there was no organized movement among Jews for a return to the Land of Israel, and there were only about 20,000 Jews living in the three "Palestinian" districts of the Ottoman Empire. Furthermore, the Ottoman Empire had lost half its territory to European penetration and nationalist revolts, and was totally opposed to the introduction of a new, Western-oriented, nonMuslim minority in the very heartland of the Empire that remained.

Today, only a century and a quarter later, the Jewish state comprises 78 percent of this territory. Its population of 7 and a quarter million includes 5 and a half million Jews, who within a few years will become the world's largest Jewish community. In fact, within a generation, Israel will become home to a majority of the world's Jews; it is already home to 41 percent of them. Israel will become the unchallenged center of Jewish life, fulfilling the unimaginable wish of the Zionist thinker Ahad Ha'am that "from this center the spirit of Judaism will go forth...to all communities of the Diaspora, and will breathe life into them, and preserve their unity."

\footnotetext{
1 Texto da Conferência inaugural do Colóquio "Religiāo, Nação e Estado nos 60 anos de Israel: geopolítica e (des)encontro de "civilizaçôes" (Coimbra, 2 de Abril de 2008, organizaçăo do CEIS20 da UC e do CADC de Coimbra).
} 
The achievements of this state are undeniable. Israel is currently ranked at $23^{\text {rd }}$ place in the world in the UN Human Development Index, which measures social and economic well-being. It is tenth in the world in life expectancy, and first in the percentage of its population with university degrees. It has more scientists and technicians, and produces more scientific papers, in relation to its size, than any other nation. It has more mobile telephones than it has people. It is especially successful in high technology, which now accounts for half of its exports. And despite strong opposition to its very existence, it has gained general international recognition and acceptance - including, very importantly, permanent peace treaties with two of the four bordering Arab states.

How did all this come about?

The story begins in Tsarist Russia, which in the late nineteenth century was home to half the world's Jews. Russia itself - that "prison house of nations" - was in great turmoil and, as so often, Jews became targets of a vicious officially-inspired anti-Semitism. In the course of four decades, an estimated four million Jewish refugees fled to more hospitable shores.

In itself, this was not a novel development; it reproduces the essential rhythm of Jewish history over the centuries. The Jewish presence in Eastern Europe was itself a result of earlier flights from persecution in Western Europe. And before that, Spanish Jews had found refuge in non-Palestinian regions of the Ottoman Empire. But in none of these cases did massive flows of Jewish refugees produce a serious organized movement for a return to Zion. The Land of Israel, in most periods of history, was simply too inhospitable and unpromising, if not forbidden. The Return to Zion was always an aspiration, a dream, and a prayer, but never a program.

Nor did Zion present a more welcoming venue in the waning days of Ottoman rule there. Ottoman authorities prohibited Jewish immigration, banned the sale of land to Jews, and systematically denied building permits for Jewish settlements. Apart from that, the Palestinian provinces of the Ottoman Empire were poor in resources and economic potential; outsiders found the landscape arid, bleak, and uninviting. Mark Twain, visiting in 1867, said that "of all the lands there are for dismal scenery, I think Palestine must be the prince... It is a hopeless, dreary, heart-broken land."

So what made this different from previous flights from persecution? Actually, for the most part it wasn't different. Of the four million Jews who left Russia between 1880 and 1920 , most followed the traditional pattern, fleeing to Western Europe and most especially to the New World. But a small handful - perhaps two percent of the whole - decided, despite the obstacles, that the time had come to rebuild Jewish life in the historic homeland. They were, in other words, a very small vanguard of intensely dedicated believers. It was said that "you don't have to crazy to be a Zionist, but it helps." Who were these crazy fanatics?

This vanguard of true believers were generally not the more religious or the more desperate of the refugees. Primarily, it was the younger, the better educated, and the more Westernized who rediscovered Zion. It was those who had pinned the highest hopes on liberalization and assimilation who were especially stunned by the new, and more vicious, racial anti-Semitism that appeared not just in Russia but throughout Europe - even, as the Dreyfus affair revealed, in the France of 
liberty, equality, and fraternity. (The Dreyfus affair was the false conviction of a French Jewish army officer for treason, which unleashed a torrent of anti-Semitic vitriol). As theorists of revolution point out, the best recipe for rebellion is to give hope to the downtrodden and then to cruelly take it away. This is what happened in Russia after 1881. As one Jewish law student recalled, "something in me snapped...in one flash all my illusions were revealed, and all the beautiful pictures of the future...dissipated like smoke."

Anti-Semitism produced a different reaction this time because of an important difference in context. On the eve of the twentieth century, nationalism, and the paradigm of the nation-state, had become dominant in political discourse, and were being extended from France, Germany, and Italy to the peoples of Central and Eastern Europe: Greeks, Hungarians, Serbs, Romanians, Bulgarians, Albanians. This had a double impact on Jews. First, they were quite naturally inclined to imitate other nationalisms. Except for the misfortune of geographic dispersion, were Jews less of a "nation" than others? Secondly, they were reacting to new threats: as other nations discovered their identiries, the result was to exclude Jews even more than in the past. Zionism was therefore not only an imitation of the nationalism of others, but also a defense against it.

The idea of Jews having their own state was not new; it was integral to Jewish history, culture, and prayers. In the course of the nineteenth century there were a number of advocates, Jewish and non-Jewish. But what sparked the movement of setrlers back to the Land of Israel was the assassination of Tsar Alexander II, the reforming tsar, in 1881; this led to a violent wave of persecution that gave birth to the term "pogrom." A manifesto of embittered Jewish students, from 1882, reflects this new turn: "O our nation... The pogroms have awakened you from your charmed sleep ... We want a home in our country. It was given to us by the mercy of God; it is ours as registered in the archives of history. [We want] to beg it of the Sultan himself ...."

The idea that the Ottoman Sultan would willingly surrender the Land of Israel indicated the level of fantasy that prevailed among these early settlers. Apart from the opposition of the Turks at every stage, a number of other serious obstacles existed: the lack of good land for sale, disease and other physical hardships, a hot and arid landscape with a scarcity of water, their own lack of knowledge or experience, and the hostility of the local population. The newcomers were scorned as Jews and hated as Europeans. Not surprisingly, their success in the first twenty years was very limited: 17 new settlements with a few thousand inhabitants. Had nothing changed, this would have remained a minor footnote in history.

But two developments did change the course of history.

One was the emergence of the first effective political movement promoting the goal of Jewish statehood. The unlikely founding figure was Theodore Herzl, a 35year old journalist and would-be playwright, who was stung into action by the Dreyfus affair and by the election of an anti-Semitic mayor in his own city of Vienna. In 1897 Herzl organized the World Zionist Organization, whose declared aim was "to create for the Jewish people a home in Palestine secured by public law."

The other new development was a renewed wave of anti-Semitism, ignited by the first Russian Revolution of 1905, that produced another wave of refugees. By 
the eve of World War I, Jews in Palestine had grown to an established community of about 80,000 , with an institutionalized framework that would serve to absorb later influxes. This pattern repeats again and again, as each outbreak of persecution produced a new wave (aliya in Hebrew) of settlers. Civil war in Russia, in the 1920 s, brought the third aliya. Anti-Semitic government policies in Poland, in the mid-1920s, led to the fourth aliya. The rise of Nazi Germany and other fascist regimes in the 1930s was the force behind the fifth aliya. The Holocaust made Zionists out of nearly all Jews, with refugees and survivors struggling to reach Palestine. And after the creation of Israel, the flight of Jews from Arab countries almost doubled the population of the country in its first decade.

In 1948 Jews constituted one-third of Palestine's population. This was made possible by the establishment of the British Mandate of Palestine, charged by the League of Nations with facilitating Jewish immigration, and by the closing off of other traditional havens of Jewish refuge. In the early 1920s the United States and other Western hemisphere nations closed their gates to mass immigration - leaving entire Jewish refugee communities with no options other than Palestine. And the war that followed Israel's creation in 1948 completed the demographic transformation through the massive outflow of Arab refugees. The new state that emerged had an Arab minority of about 19 percent, roughly the same proportion of the population as today.

Zionism sought to "normalize" Jewish life, and end the persecution of Jews, by becoming a nation like other nations. But in many respects the nation created 60 years ago was not like other nations:

$\square$ Roughly 80 percent of those who came to Israel over the years meet the standard international definition of "refugees," with all that this implies for political attitudes and insecurities.

$\square$ The nation found itself in a permanent state of war, surrounded by hostile states, relying on a strong military and with an unprecedented defense burden.

$\square$ The population includes a large minority identified ethnically with enemy states, plus a large religious minority - the ultra-Orthodox - who question the legitimacy of the state. (Surely Israel is unique as a state where about one-quarter of the Members of Parliament refuse to sing the national anthem.)

In meeting these challenges, Israel could, however, draw upon a rich Jewish experience in politics. This sounds paradoxical, given the image of persecution and powerlessness in Jewish history. But surviving two millennia of hostility required a capacity to organize and to assert collective interests - in other words, a capacity for politics. Numerous historical Jewish communities in different settings exercised a high degree of autonomy, governing their internal life in defense against a hostile environment. In Tsarist Russia, communities held their own elections, passed their own laws, taxed themselves, had their own courts and welfare systems, and even conducted their own diplomacy.

In this political culture, what stands out?

Ironically, the state founded to solve the perennial problem of Jewish security has itself been plagued by constant insecurity. The establishment of a Jewish state displaced this fear and mistrust onto an entirely new level, but the sense of being "a people that dwells alone" is still pervasive. The historic achievement of at least 
de facto acceptance by most of the Arab world and contractual peace on the country's two longest borders have not eliminated this insecurity. Despite enviable success in most spheres of life, the sense of vulnerability still prevails. The capacity to extract gloomy premonitions from even the most promising turn of events remains undiminished.

In one of the most important speeches in Israeli political history, Prime Minister Yitzhak Rabin addressed this very issue in his inaugural address in 1992:

"It is our duty to ourselves and our children, to see the new world as it is now ... . No longer are we necessarily 'a people that dwells alone,' and no longer is it true that 'the whole world is against us.' We must overcome the sense of isolation that has held us in thrall..."

\section{The Clash of Two Peoples}

The security issues of modern Israel do not derive, for the most part, from the traditional sources of anti-Semitism. They derive from the stark reality that there is another people with a claim to the same piece of land.

In introducing the Arab-Israel conflice into the discussion, it helps to get rid of persistent myths prevalent in popular folklore:

1. This is not an "age-old" conflict. Its origins lie in the Jewish "return to Zion" beginning about 125 years ago. Before that, Jews generally dwelt peacefully, though not as equals, in Arab lands.

2. This is not a conflict caused by ethnic hatreds. Clearly mutual hatred between Jews and Arabs has grown immensely over the course of the conflict, but more as a result than a cause. Again, Jewish minorities generally fared better historically among Arab or Muslim populations than in European states.

3. Nor is this a conflict rooted in religious differences. Religious issues have emerged in the course of the conflict, but Judaism and Islam recognize each other as legitimate monotheistic faiths.

What is the conflict about? At its core, it is a clash between two peoples over one land. As Israel's founding Prime Minister, David Ben-Gurion, said: "We and they want the same thing. We both want Palestine."

Did the early Zionist pioneers notice the Arab population in Palestine? Yes, they did. Did they consider the presence of this population to be a serious problem to the achievement of their goals? No, they did not. The existing residents, they reasoned, would be treated fairly and would share in the benefits of the developing homeland. It was sufficient, in this view, to better the welfare of non-Jewish residents as individuals, since they had not (yet) laid claim to a national identity and collective rights as a people. Only in 1907, a quarter century after the first settlers, did Yitzhak Epstein, a Zionist writer, first suggest that the relationship with the Arabs of Palestine was, in fact, "a question that outweighs all the others."

How can one sort out the historical claims and rights in this collision of two worlds? Jews can claim a unique 3200-year historic tie with a continuing (if sometimes small) physical presence throughout that time. Such a bond between 
a land and a people is unmatched in human history. It has been formally recognized by the League of Nations, the United Nations, by most governments- and even by the Holy Quran. There is no statute of limitations on the restoration of historical rights for an entire people; Jews were exiled from their homeland and only now have been able to return. It is a very strong case - considered in isolation from other claims.

The Palestinian case rests on the basic fact that the Palestinians were the indigenous population of Palestine 125 years ago, and did not invite European Jews to enter their homeland and transform it into an alien entity. Had they possessed self-determination at the time, Zionist settlement would never have taken place. The norms that prevail in today's world forbid such forced demographic change. Palestine has been predominantly Muslim and Arab for over a millennium, and it is only in the framework of Western imperialism, over the last two centuries, that Zionism was able to change this reality. It is a very strong case - considered in isolation from other claims.

Tragedy, it is said, is the clash of right with right. The Arab-Israeli conflict certainly fits this definition.

The conflict is marked by three distinct stages in its evolution, with a fourth stage possibly emerging at present. The first stage, from its origins to 1948, was a collision between two communities in Palestine over land and political control. Since neither side recognized the basic legitimacy of the other, the gap was unbridgeable.

The second stage, from 1948 to the early 1990s, was an interstate conflict between Israel and its Arab neighbor states, with the Palestinians temporarily eclipsed as a major independent actor. During this period four major wars were fought, but there was also a gradual disengagement as Arab states withdrew from the front line of the conflict, and Egypt and Jordan signed peace treaties with Israel.

The 1967 war between Israel and Arab states was the most important event in the conflict after Israel's birth; essentially, it marked the final stage in the reversal of power relationships. Zionists who had at first sought a foothold in historic Palestine now controlled all of it. Palestinians who saw all of Palestine as their heritage now clung to a remaining foothold under Istaeli occupation. And so long as Israel remained in occupation of the West Bank and Gaza, maintaining its positive image in the world at large became increasingly difficult, if not impossible. The image of Israel as underdog was no longer valid, which is very difficult for many Israelis and Jews to understand.

The third stage, with roors in the 1960s but fully emerging in the 1990s, was the re-emergence of the Palestinians as the major actor opposite Israel. In 1993, for the first time, there was mutual recognition and an agreed framework for solving the conflict between the mainstream leadership of the Palestinians and Israel. It appeared that the conflict was headed for resolution on the basis of a two-state solution.

A fourth stage, marked by religious extremism, seems to be taking place as we speak. I will return to this development later, but let us note the tenacity, impact and centrality of extremists in this conflict. Though a small minority on both sides, their success in subverting efforts toward resolution has been remarkable. 
Extremists, by definition, are those who believe that any means are justified in pursuit of their uncompromising goals. Though often considered crazy, they are typically very rational on the tactical level and their tactics often work. Consider the impact of Yigal Amir's assassination of Yitzhak Rabin in 1995, or the way that Palestinian terror attacks have influenced Israeli politics. The extremists on the two sides are in fact allies, who have the same goal of disrupting any move toward reconciliation and who need each other as validation for rejection of compromise.

\section{Existing and Future Challenges}

Lately challenges to Israel's well-being and very existence seem to have re-emerged and even multiplied - to the point that one recent book even asks, in its title, "Will Israel Survive?" Demographers predict that in the near future there will be more Palestinians than Jews in Palestine as a whole (considering Israel and the territories together). In the past Israel's lower birthrate was offset by immigration from "distréssed" Jewish communities under pressure to flee, but with the end of the massive influx from the former Soviet Union, these reservoirs are largely exhausted. Eighty percent of all Jews outside Israel now live in Western democratic nations, which have never produced significant flows of immigrants to Israel. In addition, the internal balance within Israel is shifting: an estimated one-quarter of immigrants from the former Soviet Union are not Jewish. When the large influx of non-Jewish foreign workers is added to the picture, it is estimated that the Jewish proportion of the population is barely above 70 percent and is declining.

To this must be added the impact of division within the Jewish population. Israel has always had deep religious splits; in recent years the numbers and impact of the ultra-Orthodox community, which is non-Zionist or even anti-Zionist, has grown greatly. An estimated 30 percent of children entering primary school in the near future will be enrolled in ultra-orthodox schools; when this is added to those attending Arab schools, over half the nation's pupils will be in schools that do not subscribe to the basic Zionist narrative.

Furthermore, the Palestinian Arab citizens of Israel have recently become more assertive in their demands for transforming Israel into a "state of all its citizens." In an important series of documents issued last year, leaders of this community challenged the basic legitimacy of a Jewish state, calling for the elimination of all elements that reflect an ethnic character - such as the right of Jews to return to Israel, or even the national anthem and flag.

The international setting also seems, in many ways, increasingly hostile to the very notion of a state founded to give expression to Jewish nationhood. Militant Islamism, with its total rejection of Jews as a people, finds expression in the renewed calls for Israel's destruction by the leaders of Iran and other extremist religious figures in the Muslim world. Furthermore Iran, guided by a messianic doctrine that envisions the end of the world, is poised to develop weapons-grade nuclear material within a period estimated variously at two to ten years. International sanctions have so far failed to halt this program, and most experts do not believe that there are viable military options to stop it. 
In addition, anti-Semitism seems to be on the rise and becoming a political factor in some European countries and elsewhere. Even U.S. support for Israel, it is said, can no longer be taken for granted, since the end of the Cold War has changed the calculus by which Israel was considered a strategic asset in U.S. policy. Indicative of this is the appearance of major books, by reputed scholars and a former President, challenging the basis for U.S. support for Israel and legitimizing the call for ending this support.

The final note of gloom in this picture brings us back to the conflict with the Palestinians.

The events of 2006, two years ago, suggested that this conflict was no longer simply a conflict over land, security, and other concrete interests. Instead, it had become what it had not been in the first 125 years: a conflict dominated by religious frames of reference.

After a century and a quarter, is the conflict entering a fourth stage in its fundamental structure?

In its earlier stages, nationalism, not religion, was the dominant force. There were religious fundamentalists and militants on both sides, but they were not in control. Two national movements were fighting over one piece of land, and it appeared that the conflict could be resolved by dividing the land. In the new reality, the fourth stage, this closing of the gap appears very much in doubt. What has emerged is a rejectionism similar to, or even more complete, than that of the first stage.

The shift began with the appearance of Hizballah, a non-Palestinian Shi'ite Arab movement in Lebanon inspired and supported by the fundamentalist government of Iran. In the aftermath of Israel's 1982 campaign to oust Palestinian forces from southern Lebanon, Hizballab proclaimed that "our struggle will end only when this entity is obliterated... . We vigorously condemn all plans for negotiation with Israel, and regard all negotiators as enemies." This was copied by the Palestinian movement Hamas - the Islamic Resistance Movement - which came into existence with the onset of the first intifada at the end of 1987. The 1988 Hamas Charter declared that all of Palestine was an Islamic trust and that every inch must be liberated, that compromise was forbidden, and that Jews were guilty of having fomented World War I, World War II, the United Nations, Communism, and capitalism.

In 2006 this process culminated in the Hamas victory in the Palestinian elections in January, and the war between Israel and Hizballah in July and August. And in June, 2007, Hamas took over complete control of the Gaza strip, meaning that any agreement between Israel and the Palestinian Authority (PA) would at best only apply to the 60 percent of the Palestinian population in the West.

Israel's war with Hizballah was a new kind of combat that left behind a pervading sense of frustration. With the help of Iran, Hizballah in Lebanon had over the years built an impressive military infrastructure including an arsenal of thousands of short- and medium-range rockets. Responding to the kidnapping of two Israeli soldiers, Israel launched a campaign, primarily from the air, that proved inadequate to inflict a decisive defeat on Hizballah forces or to stop the rain of rockets on Northern Israel. There was widespread apprehension that the Hizballah 
model would provide inspiration for Hamas in Gaza, where already a steady stream of primitive rockets was being launched at nearby Israeli towns. It was clear that, despite its military superiority, the Israeli army had no immediate solution to the problem of rockets or missiles fired from territory it did not control.

The events of 2006 put an end, for now, to the Israeli move toward unilateral disengagement from Palestinian territories. During the second intifada, support had grown for unilaterally drawing lines between Israel, on one side, and the West Bank and Gaza, on the other. On this basis, Prime Minister Ariel Sharon, long regarded as a superhawk, carried out the evacuation of Israeli settlements and forces from Gaza in late 2005, and disengagement - or "consolidation" - was the declared objective of the government formed, under the new Kadima party, after elections in early 2006. But with the intensification of attacks and threats from areas evacuated - Lebanon in 2000 and Gaza in 2005 - support for further withdrawals disappeared.

The fundamental problem, as in past periods of the conflict, is once again the absence of a Palestinian partner ready to negotiate on the basis of coexistence and able to implement a conclusive end to the conflict. In the absence of such a partner, the likelihood of intensified hostilities with Hamas in Gaza, and in the course of time with Hizballah again in Lebanon, remains extremely high.

\section{Responses and Prognosis}

Putting everything together, this seems like a rarher dismal portrait of future prospects. But as always, there is another side of the story.

Survival of the state of Israel is not in jeopardy. No serious observer believes that Istael's very existence is threatened, not even by the spectre of nuclear weapons in hostile hands. What is at stake is the kind of future that the state will have.

Regarding the demographic trends that seem to threaten, there is dispute about the numbers; some claim that Palestinian population growth has been overstated. But even if the numbers are correct, Istaelis have responded with increasing support for a two-state solution and a negotiated - not unilateral - withdrawal from Palestinian ateas. Even a unilateral withdrawal, for that matter, such as the withdrawal from the Gaza Strip in 2005 , is seen as a positive step since it greatly improves Istael's demographic situation.

Regarding Palestinians within Israel proper: Arab citizens of Israel may be demanding basic changes in the political system - but they clearly want to remain a part of it. Recent suggestions that Arab-populated areas of Israel be transferred to a Palestinian state have met with vociferous opposition from these very inhabitants.

Regarding Israel's international standing: this is in some respects at an all-time high, despite appeatances. In 1985 only 68 states maintained diplomatic relations with Israel; the number today is 162 , including some Muslim nations. Direct foreign investment in Israel grew from $\$ 537$ million in 1992 to $\$ 18$ billion - a 33 -fold increase - in 2006. Israel is one of only three nations to have free trade relations with both the United States and the Europcan Union. 
Regarding the end of the Cold War: on balance this has been a geopolitical gain for Israel, since it led to the end of unstinting Soviet support for the most hostile regimes in the region and pushed them - the Palestine Liberation Organization (PLO) in particular - into considering diplomatic options.

Regarding U.S. relations: as measured in public opinion, support for Israel remains unchanged and strong, favoring Israel by a 4-to 1 margin, and strategic cooperation - spurred by the "war on terror" - remains as high as ever.

Regarding neighboring Arab states: the disengagement of these states from the conflict, which began after the 1967 war, continues: there have been no state-to-state wars since 1973; the Arab boycott of those who deal with Israel is defunct; the Iraqi threat no longer exists; and Egypt and Jordan have even become, in a limited way, strategic partners.

Regarding the threats from Iran: these hostile attacks have attracted so much attention in large part precisely because they are so unusual in the contemporary setting. Three or four decades ago, such threats and talk of Israel's demise were too commonplace to merit any special comment.

Regarding the Iranian nuclear threat: Mr. Ahmedinejad will not be in power forever, and there are signs of considerable opposition to his extremism even within Iranian ruling circles. International pressure has forced Iran to slow down its program; potentially more international pressure could slow it down further, leaving more time for internal change in Iran. But this is part of a bigger issue: the proliferation of weapons of mass destruction in the Middle East, which is not only inevitable but is already a reality: chemical and biological weapons are already a part of the equation between Israel and Syria, for example. In the end, as in the Cold War, and between India and Pakistan, deterrence and the rational wish of self-preservation will be the key, as they have been elsewhere. A Middle East "balance of terror" already exists. It is not the world that we prefer, but it may be the world we have to live with and find ways to stabilize.

Regarding other threats to Israeli security: it should be noted that despite the lack of a ready answer to the rocket problem, other threats to daily life have been reduced. Since the high point in 2002 , the number of successful terror attacks in Israel has dropped dramatically. The security fence/wall between Israeli and Palestinian areas has been very controversial politically, but has helped to curtail infiltrations into Istaeli civilian centers.

As for the Palestinian conflict, it is important to remember that a majority on both sides, despite recent setbacks, still favor negotiation and a two-state solution. A poll of Israelis in July, 2007, showed 64 percent ready to accept a Palestinian state and even more believe it to be inevitable. 53 percent of Palestinians in November, 2007, favored a two-state solution (24 percent supported a binational state and only 11 percent called for a unitary Islamic or Palestinian state). Prime Minister Ehud Olmert, who voted against the peace treaty with Egypt in 1978 and against the Oslo agreement in 1993, now advocates positions that would have been associated with the most dovish circles in those days. The irony is that support among Israclis for a two-state solution has become dominant precisely when the prospect of a viable negotiating partner seems more remote. 
The problem, as always, is overcoming the extremists and creating a situation in which the majorities, on both sides, can prevail. The key to this is strengthening civil society in the Palestinian Authority (the West Bank at present) - a goal that Western states and Israel seem to understand and are trying to implement.

Some Palestinians still cling to idea of a unitary Palestinian or Islamic state, achieved in stages, relying on the Lebanese and Gaza model for forcing Israel out of the West Bank and on demographic trends for the eventual Arabization of Israel. This represents, however, a complete misjudgment of the strength, determination, and intelligence of Israelis, who will not allow themselves to follow this scenario blindly - and thus the strong support for separation.

Lately another model has become fashionable in some circles: the idea of a binational state, a state that would be neither Jewish nor Arab but in which the two peoples would share power in a neutral framework. The vision of Israelis and Palestinians living together cooperatively, with neither side dominating the other, is undeniably attractive. But is such a design workable in intense ethnic conflicts? Binational states have a very poor track record, outside of the two Western liberal democracies of Canada and Belgium. The idea has been applied, unsuccessfully, in Pakistan, Sri Lanka, Cyprus, Lebanon, Yugoslavia, and a number of African states. There are no apparent examples of successful power-sharing between parties still at war. It is difficult to imagine that parties having great difficulty in cooperating on terms of separation would suddenly be able to agree on intricate cooperation in all the minute details of public life.

Also conspicuously missing is any support for the binational model among major political groups on either side. In opinion surveys some 20-25 percent of Palestinians express support for a binational state, but this is clearly an expression of frustration over the current situation, or else an expression of the belief that demographic submersion would make any binational state more Arab and less Jewish over time.

A binational state would give neither side the sense of self-determination and national identity that both have defined as the core of their aspirations over the last century. In the end, a difficult divorce is better than turbulent cohabitation.

The likely terms of this divorce are actually fairly clear to most observers. We should remember that an agreed framework between Israel and the recognized Palestinian representatives, for overall settlement of the conflict, has only existed for the last 15 years of this 125-year struggle. In addition, serious negotiations between the two parties over the basic issues of the conflict - the "final status" questions - have taken place only for a few months, in 2000-2001. Nevertheless, in the light of general trends on both sides over the last few decades, and despite the setbacks of recent history, we can see the emerging contours of what a final resolution would look like.

There will be a Palestinian state alongside the Jewish state, with borders based on the pre-1967 armistice lines with minor changes. The status quo on the holy sites will remain, with the Muslim mosques (al-Aqsa and the Dome of the Rock) under Muslim control and the Western wall under Jewish control, with formal sovereignty left vague. A token number of Palestinian refugees might be reunified with families in Israel, but the right of return would be exercised primarily to 
Palestine. Palestine would have forces to maintain law and order, but not to threaten Israel. An international presence would probably be needed to guarantee the agreement.

It is much easier to predict the likely content of a settlement, however, than to predict when it will be achieved. The general trends of the last century and a quarter give us a certain degree of confidence that, sooner or later, the majorities on both sides favoring a compromise will prevail. But the events of the last few years teach us that the road to peace is rocky and has many downturns, and that we have yet a long way to travel.

\section{BIBLIOGRAPHY}

ARIAN, Asher - Politics in Israel: The Second Republic, Congressional Quarterly Press, 2005.

AVINERI, Shlomo - The Making of Modern Zionisn: The Intellectual Origins of the Jewish State, Basic Books, 1981.

BARD, Mitchell - Will Israel Survive?, Palgrave Macmillan, 2007.

DOWTY, Alan - Israel/Palestine, Polity Press, 2008, 2nd edition.

DOWTY, Alan - The Jewish State: A Century Later, University of California Press, 2001 , Updated edition.

HERZL, Theodor - The Jews' State: A Critical English Translation, Jason Aronson, 1997.

KHALIDI, Rashid - Palestinian Identity: The Construction of Modern National Consciousness, Columbia University Press, 1997.

KUMARASWAMY - P. R., Historical Dictionary of the Arab-Israel Conflict, The Scarecrow Press, 2006.

LAQUEUR, Walter and RUBIN, Barry (eds.) - The Israel-Arab Reader: A Documentary History of the Middle East Conflict, Penguin Books, 2001, $6^{\text {th }}$ edition.

MORRIS, Benny - Righteous Victims: A History of the Zionist-Arab Conflict (18812001), Vintage Books, 2001.

OREN, Michael B.- Six Days of War: June 1967 and the Making of the Modern Middle East, Oxford University Press, 2002.

PENSLAR, Detek J.- Israel in History: The Jewish State in Comparative Perspective, Routledge, 2007.

WAXMAN, Dov - The Pursuit of Peace and the Crisis of Israeli Identity: Defending/ Defining the Nation, Palgrave Macmillan, 2006.

WASSERSTEIN, Bernard - Israelis and Palestinians, Yale University Press, 2003. 